\section{Significance of low serum ferritin levels in elderly in-patients}

Sir, In our opinion, the above study ${ }^{1}$ was flawed by the implied assumption that all serum ferritin levels below $50 \mu \mathrm{g} / 1$ were equally valid for the diagnosis of iron deficiency. In actual fact, when the diagnosis of iron deficiency is validated by absence of stainable iron from a bone marrow aspirate, only serum ferritin levels $<12 \mu \mathrm{g} / 1$ possess $100 \%$ specificity for this diagnosis. ${ }^{2,3}$ The likelihood ratio for iron deficiency falls from 41.47 in elderly subjects with a serum ferritin of $\leqslant 18 \mu \mathrm{g} / \mathrm{l}$, to 3.12 in those with serum ferritin levels in the range $>18$ $\leqslant 45 \mu \mathrm{g} / 1^{4}$

Joosten $e t$ al. ${ }^{1}$ also questioned the sensitivity of a mean corpuscular volume $(\mathrm{MCV})<80 \mathrm{fl}$ as a screening test for non-anaemic iron deficiency. ${ }^{1}$ Although originally regarded as having comparable validity for the diagnosis of iron deficiency, a mean corpuscular haemoglobin $(\mathrm{MCH})<26 \mathrm{pg}^{5}$ now seems to have lapsed into disuse as a screening test. Our own unpublished observations,

Table I RBC indices in severe and in moderate hypoferritinaemia (percentage of total number of patients in parentheses)

\begin{tabular}{lcc}
\hline Subgroup & Ferritin & Ferritin $=$ \\
& $\leqslant 5.0 \mu \mathrm{g} / \mathrm{l}$ & $5.1-9.9 \mu \mathrm{g} / \mathrm{l}$ \\
\hline $\mathrm{MCV}<80 \mathrm{fl}+$ & $53 / 74(71.6)$ & $47 / 82(57.3)$ \\
$\mathrm{MCH}<26 \mathrm{pg}$ & & \\
$\mathrm{MCV}<80 \mathrm{fl}$ & $53 / 74(71.6)$ & $49 / 82(59.8)$ \\
$\mathrm{MCH}<26 \mathrm{pg}$ & $61 / 74(82.4)$ & $64 / 82(78.0)$ \\
$\mathrm{Hb} \geqslant 12 \mathrm{~g} / \mathrm{dl}$ & $5 / 74(6.8)$ & $12 / 82(14.6)$ \\
\hline
\end{tabular}

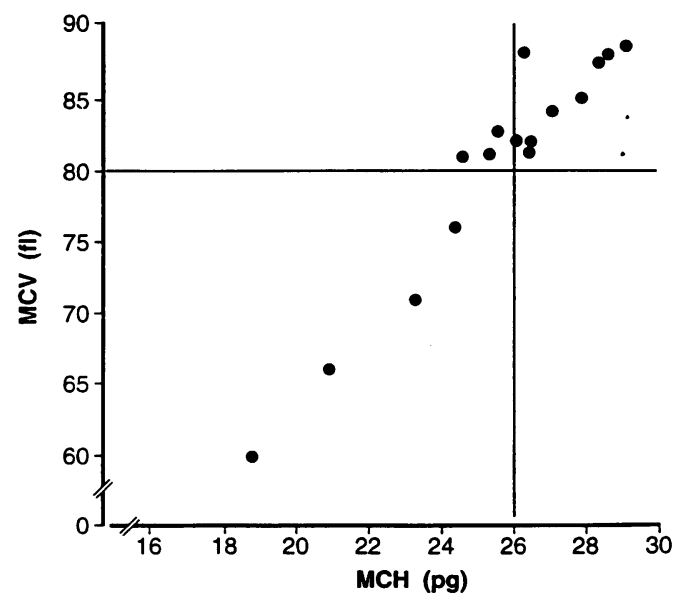

Figure $1 \mathrm{MCV}$ vs $\mathrm{MCH}$ in 17 patients (14 female and three male) with serum ferritin $<10 \mu \mathrm{g} / \mathrm{l}$ in the presence of haemoglobin $\geqslant 12 \mathrm{~g} / \mathrm{dl}$. based on 156 consecutive patients aged $\geqslant 60$ with unequivocal iron deficiency (that is, serum ferritin $<10 \mu \mathrm{g} / \mathrm{l}$ ), indicate that an $\mathrm{MCH}<26 \mathrm{pg}$ provides a more sensitive indication of underlying iron deficiency than an MCV $<80 \mathrm{fl}$. Combined results from patients with moderate hypoferritinaemia (serum ferritin $=5.1$ $9.9 \mu \mathrm{g} / \mathrm{l}$ ) as well as patients with severe hypoferritinaemia (serum ferritin $\leqslant 5.0 \mu \mathrm{g} / \mathrm{l}$ ) (Table I), showed that there were 125 patients with $\mathrm{MCH}<26 \mathrm{pg}$ vs 102 patients with MCV $<80 \mathrm{fl}$. In 100 instances both red blood cell indices fell below these cut-off levels. The subgroup of 17 patients (14 females and three males) with haemoglobin levels $\geqslant 12.0 \mathrm{~g} / \mathrm{dl}$ also showed a trend favouring greater sensitivity of an $\mathrm{MCH}<26 \mathrm{pg}$ as an index of unequivocal iron deficiency (Figure 1).

O.M.P. Jolobe H. Rakicka

Department of Medicine for the Elderly, Tameside General Hospital, Fountain Street, Ashton-under-Lyne OL6 9RW, UK.

\section{References}

1. Joosten, E., Dereymaeker, L., Pelemans, W. et al. Significance of a low serum ferritin level in elderly in-patients. Postgrag Med J 1993, 69: 397-400.

2. Ali, M.A.M., Luxton, A.W. \& Walker, W.H.C. Serum ferritin concentrations and bone marrow iron stores: a prospectiv study. Can Med Assoc J 1978, 118: 945-946.

3. Lipschitz, D.A., Cook, J.D. \& Finch, C.A. A clinical evaluation of serum ferritin as an index of iron stores. $N$ Engl J Med 1974, 290: 1213-1216.

4. Guyatt, G.H., Patterson, C., Ali, M. et al. Diagnosis of iron deficiency anaemia in the elderly. Am J Med 1990, 88: 205-209.

5. Bainton, D.F. \& Finch, C.A. The diagnosis of iron deficiency anaemia. Am J Med 1964, 37: 62-70.

This letter was shown to Dr Joosten and colleagues who reply as follows.

The recommended cut-off point for serum ferritin to discriminate between iron deficiency and non-iron deficiency varies in the literature, mostly between 12 and $20 \mu \mathrm{g} / 1$ for a non-geriatric population. These traditional cut-off points dividing normal and abnormal are not optimal. ${ }^{1}$ Patterson et $a .^{2}$ and Guyatt et al. ${ }^{3}$ clearly demonstrated that serum ferritin is the best single laboratory test to diagnose iron deficiency anaemia in elderly patients with an optimal cut-off in terms of maximizing accuracy of $45 \mu \mathrm{g} / \mathrm{l}^{1-3}$ In a similar study, we confirmed those data with a cut-off point of $50 \mu \mathrm{g} / \mathrm{l}$ as the best discriminant between iron deficiency and non-iron deficiency. ${ }^{4}$ The likelihood ratios associated with the different serum levels were as follows: 0.21 for ferritin $>$ $100 \mu \mathrm{g} / \mathrm{l} ; 0.49$ for ferritin between 50 and $100 \mu \mathrm{g} / \mathrm{l}, 7.65$ for ferritin between 20 and $50 \mu \mathrm{g} / \mathrm{l}$ and infinity for ferritin levels less than or equal to $20 \mu \mathrm{g} / \mathrm{l}$. A cut-off point of $50 \mu \mathrm{g} / 1$ corresponds with a sensitivity of $76 \%$ and a 